\title{
A New Species of Insculptoppia Mite (Acari: Oribatida: Oppiidae) from a Cave in the Southwestern U.S.A.
}

\author{
Norihide OHKUBO ${ }^{1}$ and James C. COKENDOLPHER ${ }^{2}$ \\ ${ }^{1}$ Mie Plant Protection Office, 530 Kawagita, Ureshino-cho, Mie 515-2316, Japan \\ ${ }^{2} 342856^{\text {th }}$ Street, Lubbock, Texas 79411, U.S.A.
}

(Received 17 January 2002; Accepted 5 April 2002)

\begin{abstract}
A new oribatid species, Insculptoppia cavernalis spec. nov., is described from a cave in the southwestern USA. The new species is considered a troglobite. Two specimens of 'Rasmusella n.sp. (spp.?)' in the list of fossil mites from Hidden Cave (Table 1 in Polyak et al., 2001) were also identified to be this species.
\end{abstract}

Key words: Insculptoppia cavernalis, new species, fossil mite, troglobite, cave, New Mexico

\section{INTRODUCTION}

Numerous oribatid mites were found during the course of investigations of microfossils recovered from carbonate speleothems from caves in New Mexico by one of the authors and his colleagues (Polyak and Cokendolpher, 1993; Polyak et al., 2001). They also collected extant specimens of oribatids from within the caves and on the surface near the cave entrances so that they could better understand the faunas. Some oppiid mites were among the samples. Cokendolpher submitted examples of the oppiids to Dr. Subías for identification. Subías (pers. comm., 1994) reported that two fossils and some of the extant specimens belonged to an unnamed species of Ramusella (Insculptoppia) Subías, 1980. The present authors agree with Dr. Subías' opinion on the identity of these samples except for the subgeneric status of Insculptoppia. We are not the first to list Insculptoppia as a genus. The generic status was proposed by Balogh (1983) and supported by Mahunka and Paoletti (1984), and Luxton (1985). We here give the description of the new species using extant specimens as the type series.

Insculptoppia cavernalis spec. nov.

(Figs. 1-3)

Rasmusella n.sp. (spp.?), Polyak et al., 2001: 644.

Diagnosis. Color pale. Rostrum tripartite with three rounded tips. Lamellar lines short. Sensilli with short ciliae. Notogastral setae $t i$ posterior to the level of te. Mutual distance of setae $r_{1} 0.5$ times as long as that of setae $r_{2}$. Sternal groove III parallel, deep.

Type series. All specimens collected from Hidden Cave, entrance at 2,005 m. elev., Lincoln National Forest, Guadalupe Mountains, Eddy Co., New Mexico, U.S.A. by (in February) J. C. Cokendolpher, V. J. Polyak, J. \& G. Lee, C. Belski and (August) J. C. Cokendolpher, V. J. Polyak, C. Belski, B. Eaton, C. \& J. Lee. Holotype (adult, sex undetermined) 


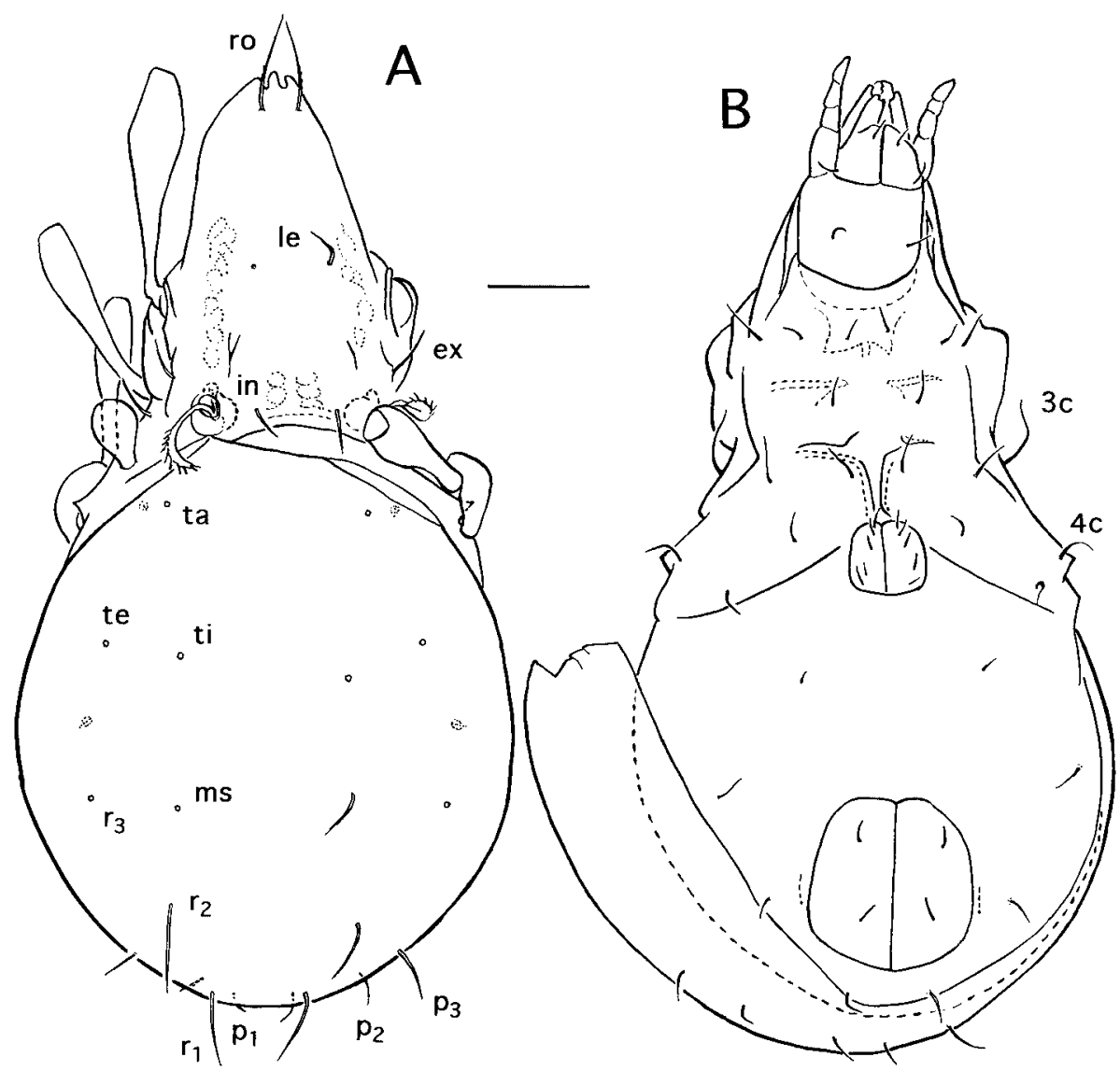

Fig. 1. Insculptoppia cavernalis spec. nov. A, dorsal aspect (Holotype); B, ventral aspect. Bar: $50 \mu \mathrm{m}$.

deposited US National Museum, Smithsonian Institution (Washington, D.C., U.S.A.), Cave Cat. \#496, 15-16 Feb. 1992, Berlese funnel extraction of wood, pine cones, and orange colored fungus from mammal nest in upper level, NE of north lake. Paratype (adult female) deposited at National Science Museum (Tokyo), the same data as the holotype. Two paratypes (adults, sex undetermined) deposited at the Museum, Texas Tech University (Lubbock, Texas, U.S.A.) and USNM-SI: Cave Cat. \#369, Field \#46, 16 Aug. 1992, dark zone, lower cave, in water; Cave Cat. \#346, Field \#AA—vacuum sample, 15 Aug. 1992, dark zone on wet wall upper cave, monohydrocalcite room.

Additional Material. 2 fossils digested from stalagmite \#89037 from Hidden Cave (see Polyak, 1992; Polyak et al., 2001 for details) and deposited at USNM-SI. Fossil specimens are not included in the type series.

Etymology. Specific name from Latin feminine adjective meaning "pertaining to cave", derived from the dwelling site of the species.

Measurements and color. Body length: $450 \mu \mathrm{m}$ (holotype); 420-460 $\mu \mathrm{m}$ (3 paratypes). Color pale yellowish-brown. 


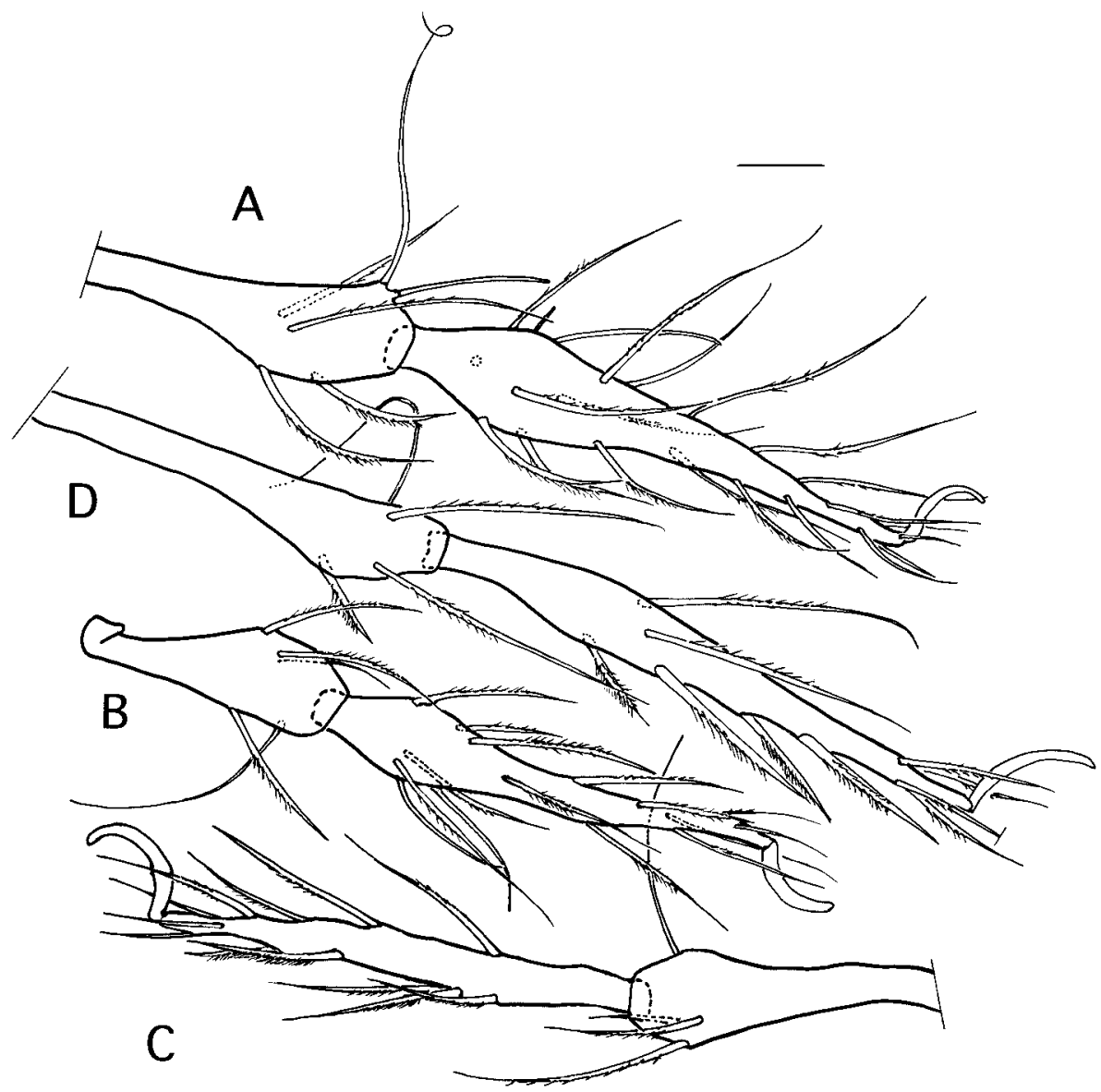

Fig. 2. Insculptoppia cavernalis spec. nov. A to D, Legs I to IV (Holotype). Bar: $20 \mu \mathrm{m}$.

Prodorsum. Prodorsum rather slender. Rostrum tripartite; each lobe rounded at tip. Lamellar lines short, just anterior to bothridia. All prodorsal setae weakly barbed. Rostral setae ro slightly curved. Lamellar setae le shorter than rostral setae; longer than the mutual distance of setae ro but shorter than that of setae in. Interlamellar setae in as long as setae ro. Exobothridial setae $e x$ as long as setae le. Sensillus fusiform with unilateral short ciliae.

Notogaster. All notogastral setae except $t a$ smooth, tapering, pointed at tip; ta existing as alveoli. Setae $t i$ posterior to the level of $t e$. Mutual distance of setae $r_{1} 0.5$ times as long as that of setae $r_{2}$.

Ventral side. Sternal groove III parallel, deep. Anterior border of epimeron III well developed. Epimeral setae $3 c$ and $4 c$ longer than the others. Five pairs of genital setae divergent posteriorly except for the posteriormost pair.

Legs. Setal formulae (famulus included): I (1-4-2-4-20), II (1-4-2-4-13), III (2-2-1$3-13)$, IV (1-2-2-3-10). Solenidial formulae: I (1-2-2), II (1-1-2), III (1-1-0), IV (0-1- 


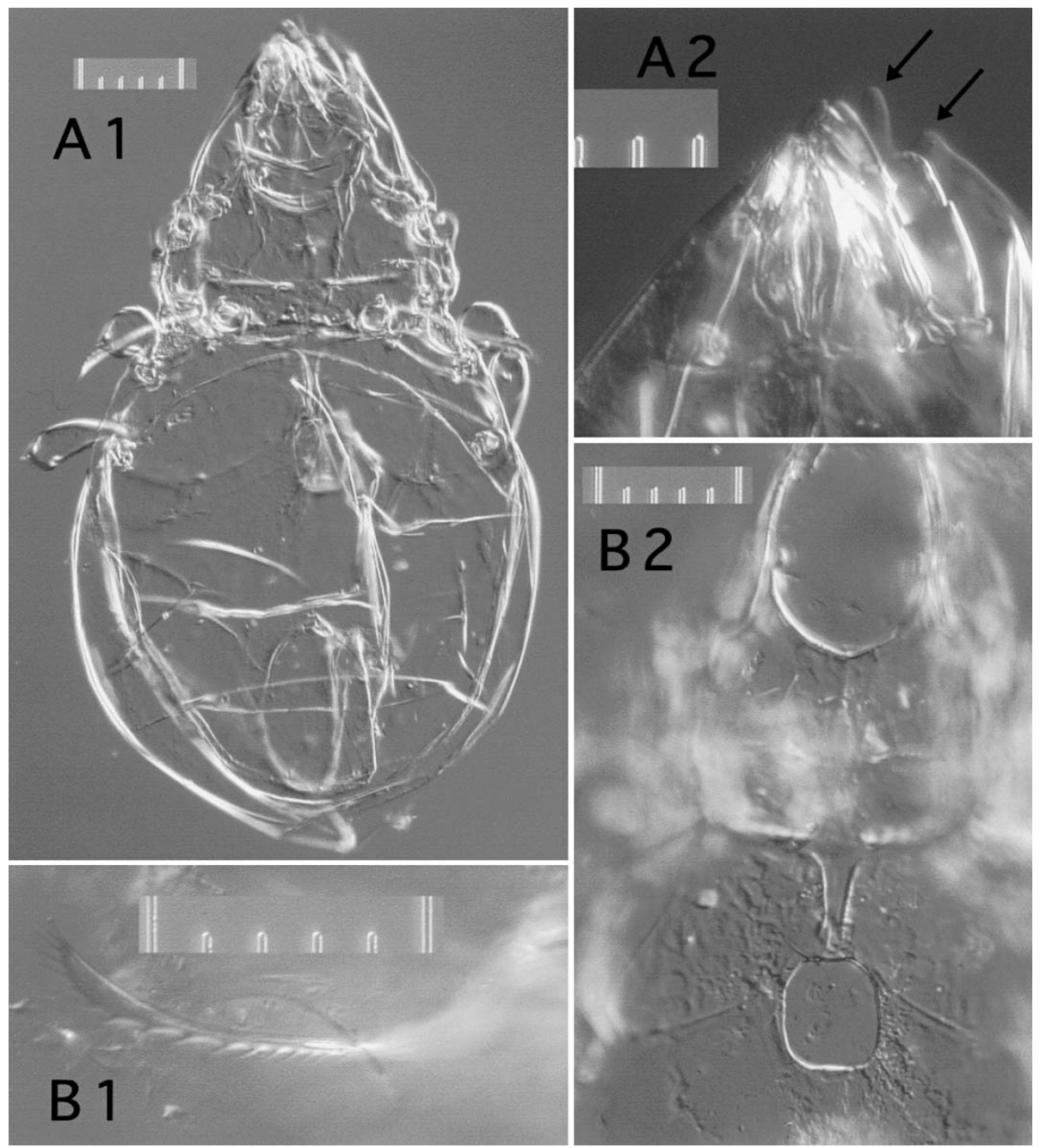

Fig. 3. Insculptoppia cavernalis spec. nov., digested from stalagmite \#89037. A, Specimen labeled "4"; A1: Whole aspect, fairly depressed; A2: Ventral aspect of anteriormost part, with rostral lobes indicated by arrows. B, Specimen labeled “48”; B1: Senssilus, B2: Epimeral region. Scale unit $10 \mu \mathrm{m}$.

$0)$. Claws slender, weakly curved.

Remarks. The Insculptoppia species of which the rostral tip is not smoothly rounded are rather few; only four such species are hitherto known. According to the figure by Balogh (1961), I. soror Balogh 1958 shows a pair of very weak incisions at the rostral tip. According to the figure by Bernini (1980), the rostral tip of I. berninii Pérez-Iñigo 1975 is deeply notched. I. corniculata (Pérez-Iñigo et Pena 1997) comb. nov. has some pointed dents on the rostrum. Ramusella (Insculptoppia) corniculata Ivan et Vasiliu 1999 hom. nov.* non

* Ramusella (Insculptoppia) corniculata Ivan et Vasiliu 1999 is a junior primary homonym of R. (I.) corniculata Pérez-Iñigo et Pena 1997. We have notified Dr. Ivan to provide a new name. 
Pérez-Iñigo et Pena 1997 has two pointed dents at rostrum. The new species is easily distinguished from these species by deeply tripartite rostrum.

Notes. Two fossils, or more precisely subfossils, are only at most 3200 years old (Polyak et al., 2001). The fossil samples are damaged and incomplete. Even so, it can be determined that they do not differ significantly from the extant material as follows. The most characteristic feature of this species is the shape of rostral tip. The feature can be well observed in one fossil sample (Fig. 3, A2). Though shape of sensillus may be often specific in this genus, no difference can be seen between extant and fossil samples (Fig. 3, B1). Structures of epimeral region also show no defference between them (Fig. 3, B2). Body length of fossils is about $420 \mu \mathrm{m}$, that is in the range of extant samples.

\section{ECOLOGY}

Cokendolpher and colleagues carefully searched the surface (by Berlese funnel extraction of litter and under rocks and debris) and Hidden Cave once each season for a year. The new species was only collected within the cave (in total darkness). Because samples were obtained during the coldest and hottest seasons (February and August, respectively), it is likely that mites were present year-round but were just overlooked on other trips (May and October). In all, four mites were collected. Two individuals of mites were collected on water in the cave. The others were taken by non-selective collection methods: vacuum and Berlese sampling. A relatively large baited and unbaited pitfall trap sampling project both in and outside of the cave was undertaken during February (winter) and August (summer) (see Cokendolpher, et al., 2001). Because no specimens were obtained of the new species, we suggest that the new species is either not very mobile or is not attracted to various baits. Though it does not show troglomorphy in the elongation of the appendages, it is lighter in color than other typical congeners. This suggests that the cuticle is thinner in response to the constantly moist environment. The condition of this troglomorphic character and the only known occurrence being from the dark zone of a cave suggest that this species is a troglobite that is restricted to life underground in a moist karst environment. Considering that extant mites were collected from wet walls of the cave as well as water in puddles on the floor, it is not surprising that they also were obtained as subfossils that were engulfed in the calcite of cave formations. This same form of entrapment and calcification was proposed for other mites discovered in this same cave (Blaszak, et al., 1995; Polyak et al., 2001).

\section{Acknowledgements}

We thank Dr. Luis Subías (Universidad Complutense, Madrid, Spain) for his observations on the species described herein. JCC received a basic research grant from the National Speleological Society to support the invertebrate survey of Hidden Cave. We are grateful to Mr. Ransom Turner and the Lincoln National Forest Service for collection permits and field assistance. We would also like to thank the many collectors that assisted in the sampling at Hidden Cave. Although it may seem odd that it would require so many people to catch a tiny mite, it is required when equipment has to be carried across a mountain and then repelled into the precipitous $25 \mathrm{~m}$ entrance drop. Many hands and eyes are also needed to 
search every rock and piece of debris in this more than $60 \mathrm{~m}$ long cave.

\section{REFERENCES}

Balogh, J. (1961): Descriptions complementaires d'Oribates (Acari) d'Angola et du Congo (2 ${ }^{\text {ere }}$ serie). Publ. cult. Co. Diam. Ang., Lisboa, no. 52: 65-74.

Balogh, J. (1983): A partial revision of the Oppiidae Grandjean, 1954 (Acari: Oribatei). Acta Zool. Acad. Sci. Hung., 29(1-3): 1-79.

Bernini, F. (1980): Notulae oribatologicae XXIV. Gli acari Oribatei de alcune piccole grotte del Senese. Redia, 63: 359-405, tab. I-III.

Blaszak, C., J. C. Cokendolpher and V. J. Polyak (1995): Paleozercon cavernicolous n.gen., n.sp., fossil mite from a cave in the southwestern U.S.A. (Acari, Gamasida: Zerconidae), with a key to Nearctic genera of Zerconidae. Internal. J. Acarol., 21(4): 253-259.

Cokendolpher, J. C., R. K. Lawrence, and V. J. Polyak (2001): Seasonal and site-specific bait preferences of crickets and diplurans in Hidden Cave, New Mexico. Texas Mem. Mus., Speleol. Monogr., 5: 95-104.

Luxton, M. (1985): Cryptostigmata (Arachnida: Acari): a concise review. Fauna of New Zealand, 7, 112 pp.

Mahunka, S. and M. G. Paoletti (1984): Oribatid mites and other mites (Tarsonemidae, Anoetidae, Acaridae) from woods and farms monocultivated with corn in the low laying plain (Veneto and Friuli, N-E Italy). Redia, 67: 93-128.

Pérez-Iñigo, C. and M. A. Pena (1997): Acaros oribatidos (Acari, Oribatei) de Gran Canaria (III). Boln. Asoc. esp. Ent., 21(3-4): 165-183.

Polyak, V. J. (1992): The mineralogy, petrography and diagenesis of carbonate speleothems from caves in the Guadalupe Mountains, New Mexico. Unpubl. M. S. Thesis, Texas Tech Univ., Lubbock, Texas, U.S.A., xvi+165 pp.

Polyak, V. J. and J. C. Cokendolpher (1993): Recovery of microfossils from carbonate speleothems. NSS [Nat'l. Speleo. Soc.] Bul. 54(1992): 66-68.

Polyak, V. J., J. C. Cokendolpher, R. A. Norton and Y. Asmerom (2001): Wetter and cooler late Holocene climate in the southwestern United States from mites preserved in stalagmites. Geology, 29(7): 643-646.

Subías, L. S. (1980): Oppiidae del complejo “clavipectinata-insculpta”. Eos, 54(1978): 281-313.

\section{摘 要}

アメリカ合衆国の洞窟のツブダニ科の 1 新種 大久保憲秀（三重病害虫防除所）・James C. COKENDOLPHER（Texas, U.S.A.）

ニューメキシコ州の洞窟から採集された, 洞窟性と思われるササラダニの新種を Insculptoppia cavernalis として命名・記載した. この洞窟の石简から取り出された化石標本の 一部は本種であると同定された。 